\title{
Glucose intolerance due to heavy metals intoxication in the rat.
}

\author{
Sohair A. Moustafa \\ Department of Zoology, Faculty of Science, Ismailia, Egypt
}

\begin{abstract}
Data of the current study show that intraperitoneal (i.p.) injection of cadmium chloride $\left(\mathrm{CdCl}_{2}\right)(5 \mathrm{mg} / \mathrm{kg})$ into male albino rats was found to induce a deterioration in glucose tolerance $24 \mathrm{hr}$ post-treatment, which was accompanied by a reduced elevation in serum insulin levels inresponse to the glucose challenge. $\mathrm{CdCl}_{2}$ produced a significant decrease in the liver content of both glutathione and protein contents 24 hours post $\mathrm{CdCl}_{2}$ treatment while a significant elevation in liver thiobarbeturic acid (TBA)-reactants was observed. A significant decrease in serum total proteins was noticed due to $\mathrm{CdCl}_{2}$ treatment while the serum levels of the two aminotransferases enzymes AST \& ALT were in significantly changed affected by cadmium intoxication. The present study suggest that the glucose intolerance observed due to $\mathrm{CdCl}_{2}$ intoxication could be due to the elevation of lipid peroxidation (induced by cadmium) which may affect the rate of glucose transport into the cells. Impaired insulin synthesis and the inactivation of the glucose metabolizing enzymes which could be secondary effects to the glutathione depleting effects of cadmium, were also suggested to be contributing mechanisms to the deterioration of glucose tolerance in cadmium intoxicated rats.

The present study throw more light on one of the most serious phases of cadmium toxicity which emphasizes the importance of performing more studies to explore all the consequences of heavy metals pollution. This could be a gate way to determine means for protection against this pollution.
\end{abstract}

\section{Key Words: Glucose tolerance; Cadmium; Rats}

\section{Introduction}

$\mathrm{Cd}$ exists in the air and water pollutants. Its toxic effects on biological systems has been extensively reported (Mennear, 1979; Ahokas et al., 1980; Lewis, 1997 and Moustafa, 2000, 2002). Free radicals are evolved at the early stages of cadmium (Cd) intoxication (Ochi et al., 1987, Richelmi et al., 1989). Oxidative stress defined as a persistent imbalance between the production of highly reactive molecular species (chiefly oxygen and nitrogen) and antioxidant defense, is implicated in a broad variety of chronic and acute diseases, including such age-related diseases as diabetes (Oh-Ishi et al., 2003 and Varvarovska et al., 2003). Earlier studies have reported the involvement of oxidative stress in the development of impaired carbohydrate metabolism in systems involving different cytotoxins Moustafa (1998) investigating the effects of glutathione depletion due to allyl alcohol treatment on carbohydrates metabolism.. In spite of the existence of plenty of studies describing the deleterious effects of $\mathrm{Cd}$ on different biological functions, only 
few reports have addressed the impact cadmium toxicity on carbohydrate metabolism. The current study was undertaken to give more insight to the relationship between cadmium toxicity and glucose metabolism. The effect of cadmium chloride $\left(\mathrm{CdCl}_{2}\right)$ on glucose tolerance and other parameters related to glucose metabolism was also investigated.

\section{Materials and methods}

\section{Animals and Experimental protocol}

Male Albino rats were obtained from the National Research Center (Cairo, Egypt). Rats were housed three per cage and allowed free access to standard chow and water except in those experiments utilizing fasted rats, where food was withheld for $24 \mathrm{hr}$. Cadmium chloride $\left(\mathrm{CdCl}_{2}\right)$ dissolved in saline, was given intraperitoneally (i.p.) at the dose of $5 \mathrm{mg} / \mathrm{kg}$ (Moustafa, 2003). Control rats were given an equivalent volume of saline. Blood and tissue samples were obtained $24 \mathrm{hr}$. post treatment.

\section{Glucose tolerance and plasma insulin}

Intraperitoneal (i.p.) glucose tolerance test was performed $24 \mathrm{hr}$ after $\mathrm{CdCl}_{2}$ treatment. Glucose load (3 $\left.\mathrm{g} / \mathrm{kg}\right)$ was given to 24 hours-fasted rats and blood samples were obtained from lightly anesthetized rats with ether from the orbital sinus at $0,30,60$ and 120 minutes post glucose loading.

\section{Determination of tissue and serum metabolites}

The rats were killed by decapitation and the livers were rapidly excised, immediately rinsed in saline, trimmed and quickly weighed. For the determination of liver GSH content, 4 parts of $0.15 \mathrm{M} \mathrm{KCl}$ were added to each liver specimen for homogenize - ation. The homogenates were used for the determination of GSH as described earlier by Tiez (1969). Liver homo genates $10 \% \mathrm{w} / \mathrm{v}$ in cold water were used for the estimation of lipid peroxidation level by the thiobarbituric acid (TBA) test according to the method of Uchyama and Mihara (1978). Tissue homogenate $(100 \mathrm{mg}$ tissue/ml) was used for the determination of the liver content of total proteins.( Serum samples and liver homogenates were analyzed by the staff at the Clinical Pathology Laboratory in the Faculty of Medicine, Suez Canal University). A Hitachi 704 autoanalyzer was used for the determination of serum aminotra nsferases: aspartate amino-transferase (AST) and alanine amino-tranferase (ALT), serum total proteins and the liver content of total proteins. Plasma insulin was measured using the insulin radioimmunoassay as described by Reeves (1983).

\section{Results}

Effect of $\mathbf{C d C l}_{2}$ on Glucose tolerance and plasma insulin

$\mathrm{CdCl}_{2} \quad(5 \mathrm{mg} / \mathrm{kg}$ )-treated rats showed significant increases in blood glucose levels 30, 60 and 120 minutes post glucose administration as compared to control rat (Fig 1). On the other hand, glucose intolerance in $\mathrm{Cd}$ treated rats was accompanied by a significantly reduction elevation in insulin levels in response to glucose stimulation 30 and 60 minutes after glucose administration as compared to control rats (Fig. 2).

\section{Effects of $\mathrm{CdCl}_{2}$ on hepatic Total proteins glutathione and lipid peroxidation (Thiobarbituric acid [TBA] reactants).}

The results in table (I) represent the toxic effect of $\mathrm{CdCl}_{2}$ on hepatic cells, as 
indicated by its marked depletion of hepatic total proteins \& GSH and its induction to a significant elevation in TBA reactants in the liver of rat.

Effects of $\mathrm{CdCl}_{2}$ on serum metabolites

Data in table (I) indicate a significant decrease in the serum total protein levels in the $\mathrm{CdCl}_{2}$-treated group, while it didn't induce any significant change in the serum levels of the liverspecific enzymes (AST \& ALT) activities.

\section{Statistical analysis}

The data were analyzed using one way ANOVA.

Table 1.Effect of $\mathbf{C d C l}_{2}$ intoxication on same liver and serum parameters in control and $\mathrm{CdCl}_{2}$-treatede rats.

\begin{tabular}{|l|c|c|}
\hline & Control group & CdCl $_{2}$-treated group \\
\hline Liver GSH ( $\boldsymbol{\mu g} / \mathbf{g})$ & $10271.86 \pm 2072$ & $6325.75 \pm 294.7^{*}$ \\
Liver TBA & $0.032 \pm 0.008$ & $0.119 \pm 0.014^{*}$ \\
Total protein & & \\
Liver (mg/g) & $120.52 \pm 11.5$ & $70.22 \pm 9.2^{*}$ \\
Serum (mg/d) & $5.09 \pm 0.983$ & $3.49 \pm 0.06^{*}$ \\
Serum AST (U/I) & $121 \pm 11.2$ & $135 \pm 12.1$ \\
Serum ALT (U/l) & $47.8 \pm 5.7$ & $63.7 \pm 7.9$ \\
\hline
\end{tabular}

Rats were intraperitoneally (i.p.) treated with $5 \mathrm{mg} / \mathrm{kg}$. Data represent the means \pm S.E of at least 5 animals. Serum and tissue samples were collected $24 \mathrm{hr}$-post treatment. $* \mathrm{P} \leq 0.05$.

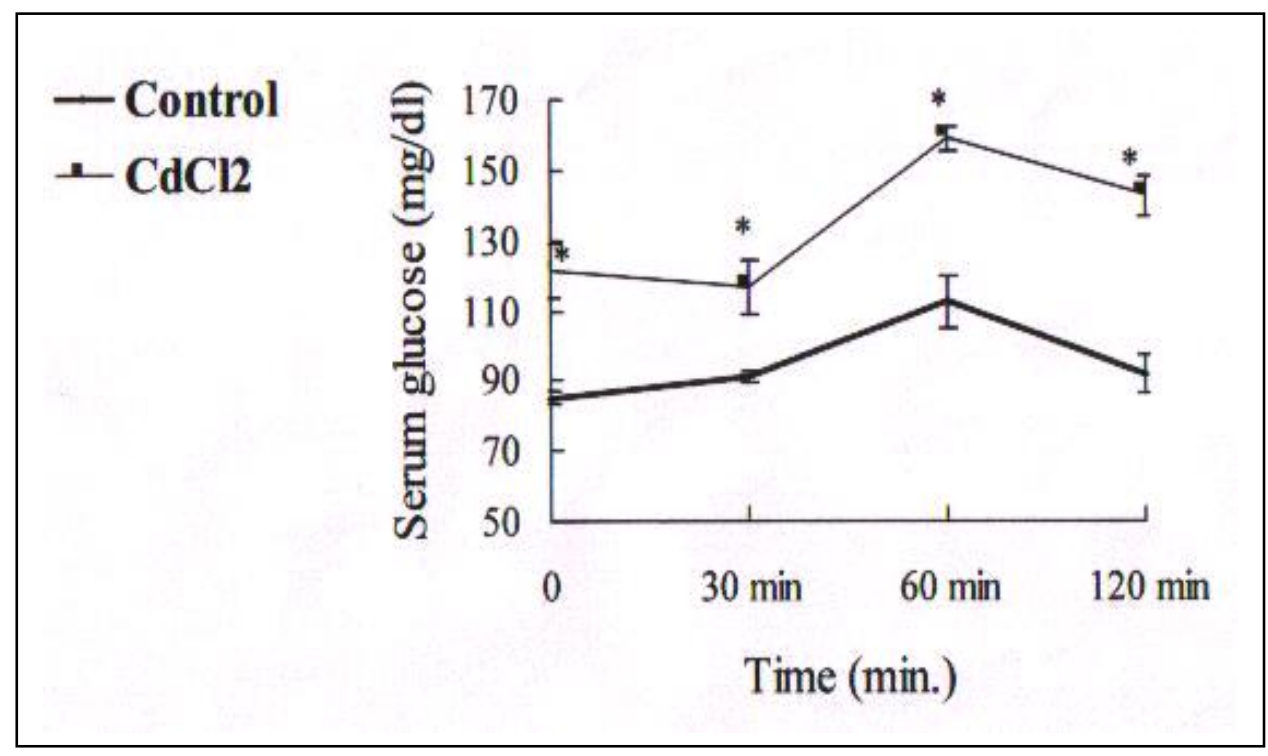

Figure 1:- Serum glucose responses to an intraperitoneal(i.p) glucose challenge(3 $\mathrm{gm} / \mathrm{kg})$ in control and i.p. injected rats with $\mathrm{CdCl} 2(5 \mathrm{mg} / \mathrm{kg})$. Experiments were performed $24 \mathrm{hr}$ after $\mathrm{CdCl}_{2}$ intoxication. Results represent the mean $\pm \mathrm{SE}$ of at least five rats. Significantly different from control:* $\mathrm{P} \leq 0.05$. 


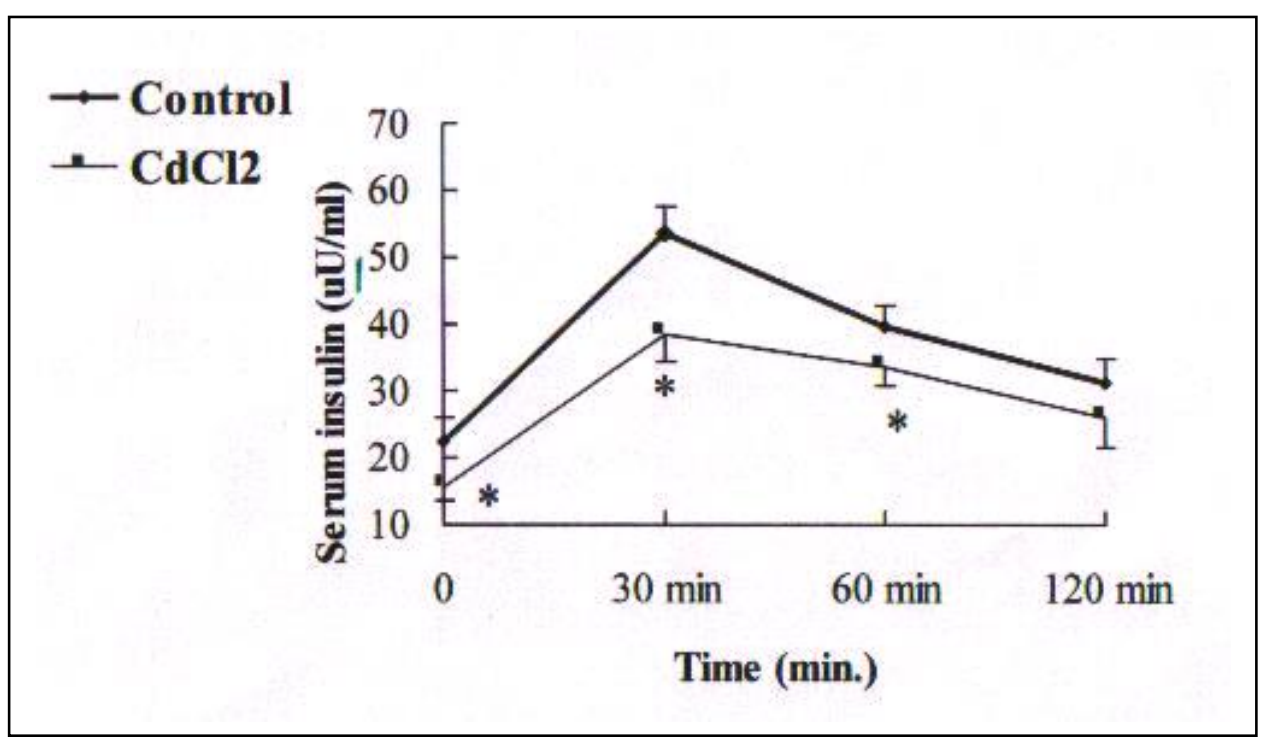

Figure 2:- Serum insulin responses to an intraperitoneal (i.p) glucose challenge $(3 \mathrm{gm} / \mathrm{kg})$ in control and i.p. injected rats with $\mathrm{CdCl} 2(5 \mathrm{mg} / \mathrm{kg})$. Experiments were performed $24 \mathrm{hr}$ after $\mathrm{CdCl}_{2}$ intoxication. Results represent the mean $\pm \mathrm{SE}$ of at least five rats. Significantly different from control:* $\mathrm{P} \leq 0.05$.

\section{Discussion}

Glucose intolerance observed in cadmium chloride-intoxicated rats could be mediated through different mechan isms. Cd-mediated free radicals produc tion could be involved in the increase in lipid peroxidation in the livers of $\mathrm{CdCl}_{2-}$ treated rats. Peroxidation of the lipid moiety of the cellular membrane may distort the structural integrity of these membranes, thereby modifying their functions. One of the most important functions of the cell membrane is the transport of various molecules into and out of the cells. Therefore, increased lipid peroxidation due to cadmium treatment may impair the rate of glucose transport into the cells. Glucose transport was reported to be the rate limiting step for overall glucose metabolism (Elbrink and Bihler, 1975). So impaired glucose transport could be the mechanism behind the development of glucose intolerance in $\mathrm{CdCl}_{2}$-intoxicated rats. Indeed, it has been suggested that free radicals are behind the development of glucose intolerance in $\mathrm{Cd}$ - treated rats (Moustafa, 1998), Alloxan-treated rats (Moustafa, 2003) and in aged rats (Moustafa et al., 1995).

On the other hand, accumulation of lipid peroxidation products in the process of organismal aging causes changes in the activity of erythrocyte membrane adenylate cyclase and protein kinase (Pfeffer \& Swislocki, 1976), influences the functions and the stability of hemoglobin (Kikugawa et $a l .$, 1984) and disturbs aminophos pholipid organization (Jain, 1984). These effects may impose serious consequences to glucose metabolism. They may affect cell hormonal interact tion therefore, disturb the action of the hormones that regulate carbohydrate metabolism.

Another possible mechanism for the development of impaired glucose tolerance in $\mathrm{CdCl}_{2}$-intoxicated rats is impaired insulin synthesis. The observed $\mathrm{CdCl}_{2}$-induced hypoinsulinemia has also 
been reported in the study of Merali and Singhal (1975). The same study has shown that $\mathrm{Cd}$ intoxication in the rat was associated with a decreased pancr eatic secretory activity as evidenced by lowered insulinogenic indices and marked inhibition of phentolaminestimulated insulin release. $\mathrm{CdCl}_{2}$-indu ced hypoinsulinemia could be attributed to an adrenaline response since adrenaline is known to inhibit insulin secretion. Stress-induced incr -ease in adrenalin secretion after drug intoxi cation has previously been reported (Kim and Na, 1991). Alternatively, the observed glutathione depletion in $\mathrm{CdCl} 2$-treated rats may cause perturb ations in the redox potential of cells which alters many important functions including biosynthetic reactions (Hazelton and Calvin, 1980). This could mean a direct effect of $\mathrm{CdCl}_{2}$ on the biosynthetic capacity of the pancreatic islets, leading to impaired insulin synt hesis. The decreased protein content in the serum and livers of $\mathrm{CdCl}_{2}$-treated rats supports this hypothesis.

Glucose intolerance induced by cadmium chloride administration may be mediated through enhanced glycog enolysis and the stimulated glucose release from its stores. The stimulating effect of $\mathrm{CdCl}_{2}$ on the glycogenolytic enzyme adenylcyclase as evidenced by its ability to increase the concentration of hepatic cyclic adenosine monoph osphate markedly (Merali and Singhal 1975). and its effect of significantly increasing the activities of the hepatic enzymes fructose 1,6-diphosphatase and glucose 6-phosphatase (Merali and Singhal 1975) give a support support to this idea.,

Additionally, $\mathrm{Cd}$ was reported to tie up the $\mathrm{SH}$ group of the protein layers resulting in S-Cd-S linkage (Kleinfeld, et al., 1955). Moreover, it has been reported that Heavy metals may react with enzymes, both soluble or membrane components, either by displacing the metal physiologically associated with the protein molecules or by binding to their functional groups (sulfhydryl, carboxyl, etc.) (Eichorn, 1973). This effect of cadmium could mean the inactivation of the family of the SH-dependent enzymes that regulate carbohydrates metabolism. This could be one of the mechanisms accounting for the glucose intolerance resulting from $\mathrm{CdCl}_{2}$ intoxication.

In conclusion the current study confirms the hazards of exposure to environmental pollution including exposure to heavy metals and reveals an important phase of cadmium toxicity. as its deleterious effects on carbohdrates metabolism. However further studies are needed to investigate the following points: a- The effect of $\mathrm{CdCl} 2$ toxicity on the rates of insulin synthesis \& secretion. b- Relationship between $\mathrm{CdCl} 2$ toxicity and the number and the affinity of insulin receptors. c- Effect of lipid peroxidation on the rates of basal and insulin-stimulated glucose transport and metabolism (rat adipocytes are recommended as a cellular model for these studies).

\section{References}

1. Ahokas, R.A.; Dilts, P.V. and Lahaya, E. (1980): Cadmium induced fetal growth retardation. Protective effect of excess dietary Zinc. Amer. J. Obstet. Gynecol. (136): 216-221.

2. Eichorn, G.L. (1973): Inorganic Biochemistry (Amsterdam: Elsevier Biomedical Press).

3. Elbrink, J. and Bihler, I. (1975): Membrane transport: Its relation to basal metabolic rate. Science (188): 117-118.

4. Hazelton, A. and Calvin, A.L. (1980): Glutathione contents in aging mouse. Biochem. J. (188): 25-30. 
5. Jain, S.K. (1984): The accumulation of malondialdehyde, a product of fatty acid peroxidation, can disturb amino phospholipid organization in the membrane bilayer of human erythr ocytes. J. Biol. Chem.( 259): 33913394.

6. Kim, E. and Na, K.J. (1991): Effect of sodium dichromate on carbohydrate metabolism. Toxicol. Appl. Pharmacol. (110): 251-258.

7. Kikugawa, K.; Kosugi, H. and Asakura, T. (1984): Effect of malo ndiladehyde, a product of lipid peroxi dation on the function and stability of hemoglobin. Arch. Bio. Biophys. (229): 7-14.

8. Kleinfeld, H., Greene, H., Stein, E., and Magin, J. (1955): Effect of the cadmium ion on the electrical and Mechanical activity of the frog heart. Am. J. Physiol. (181): 35-38.

9. Lewis, R. (1997): Occupational exposures. In. Occupational \& Environmental Medicine (LaDou, J.Edt.) 2nd edition. Prentice-Hall International, Inc. pp. 412-414.

10. Mennear, J.H. (1979): Cadmium toxicity. Edited by Mercel Dekker, New York.

11. Merali Z, Singhal RL. (1975): Protective effect of selenium on certain hepatotoxic and pancreotoxic manif estations of subacute cadmium admini stration. J Pharmacol. Exp. Ther. Oct;195(1):58-66.

12. Moustafa, S.A. (1998): Effects of glutathione depletion on carbohydrate metabolism in the rat. Res. Commun. Pharmacol. Toxicol. 3 (1\&2): 55-64.

13. Moustafa, S.A, (2002): Impaired microsomal conversion of thyroxin $\left(\mathrm{T}_{4}\right)$ into triiodothyronine $\left(\mathrm{T}_{3}\right)$ and cadmium intoxication in elderly. The Egyptian journal of Hospital Medicine .7: 126140.

14. Moustafa, S.A. (2003): Cytotoxic effects of alloxan in the rat. Mechanism and protection with Zinc. The Egyptian journal of Hospital Medicine .(7): 126-140.
15. Moustafa, S.A.; Webster, J.E. and Mattar, F.E. (1995): Effects of aging and antioxidants on glucose transport in rat adipocytes. Gerontology (41): 301307.

16. Moustafa, S.A.; Nabil, Z. I., And Ahmed, S.H. (2000). Protective effects of zinc against cadmium chloride cytotoxicity in the rat. Res.Commun. Pharmacol. Toxicol, 5: 205-220.

17. Ochi, T.; Takashi. K., Ohsawa, M. (1987). Indirect evidence for the induction of a pro oxidant state by cadmium chloride in cultured mamm alian cells and a possible mechanism for the induction. Mut Res. 180: 257266.

18. Oh-Ishi, M.; Ueno, T. and Maeda, T. (2003): Proteomic method detects oxidatively induced protein carbonyls in muscles of a diabetes model Otsuka Long-evans Tokushima Fatty (OLETF) rat. Free Radic. Biol. Med. 34(1): 1122.

19. Pfeffer, S.R. and Swislocki, N.I. (1976). Age-related decline in the activities of erythrocyte membrane adenylate cyclase and protein kinase. Arch. Biochem. Biophys. 177: 117-122.

20. Richelmi, P., Mirablli, F.; Bellomo, G. and Berte, F. (1989). on the role of mitochondria in $\mathrm{Cd}^{2+}$ toxicity in hepatocytes. Proceedings of the V International congress of toxicology, Brighton (England), P.156.

21. Tieze, F. (1969): Enzymic method for quantitative determination of nanogram amounts of total and oxidized glutat hione. Applications to mammalian blood and other tissues. Anal. Biochem. (27): 502-522.

22. Uchiyama, M. and Mihara, M., (1978): Determination of malonal dehyde precursor in tissues by the thiobarbituric test. Anal. Biochem. (86): 271-278.

23. Varvarovska, J.; Racek, J.; Stozicky, F.; Soucek ,J.; Trefil, L. and Pomahacova, R. (2003): Parameters of oxidative stress in children with Type 1 diabetes mellitus and their relatives. J. Diabetes Complications. 17(1): 7-10. 


\title{
القصورفي احتمال الجلكوز نتيجة للتسمم بالمعادن الثقيلة في الجرذان
}

\author{
سهير عبد الله مصطةي \\ قسم علم الحيو ان, كلية العلوم, جامعة قناة السويس, الإسماعيلية, مصر
}

تتنير نتائج الدر اسة الحالية إلي أن الحقن البريتوني لذكور الجرذان بمادة كلوريد

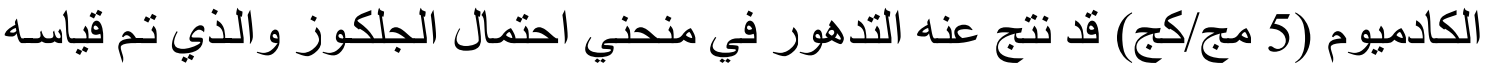

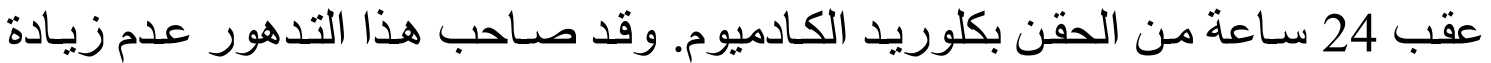

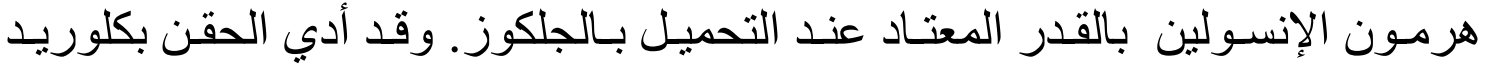

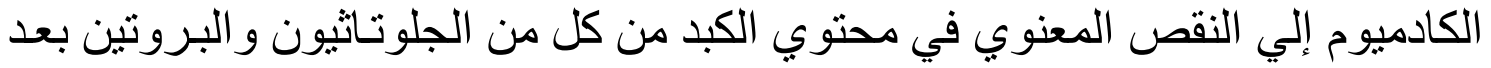

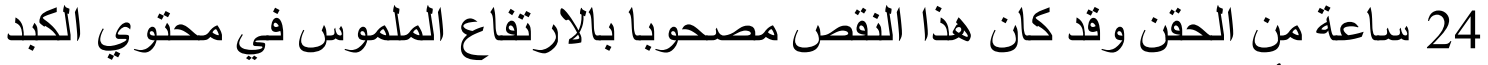

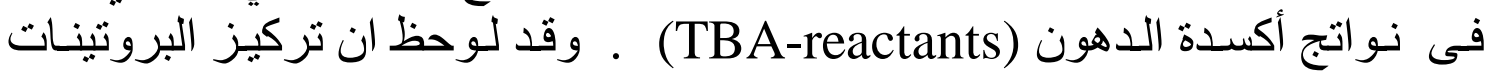

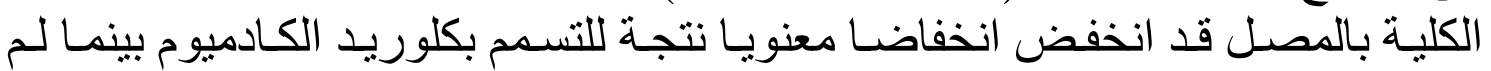

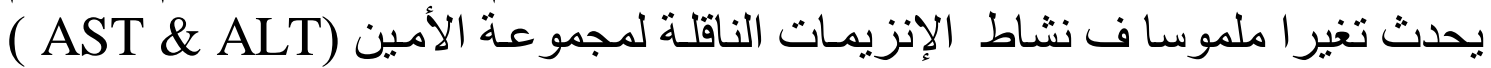

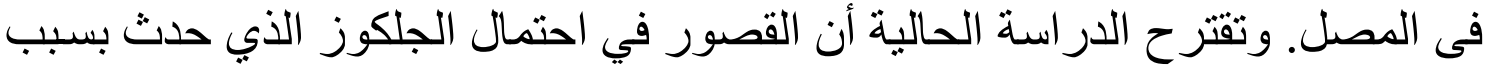

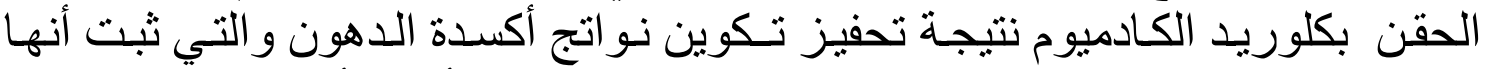

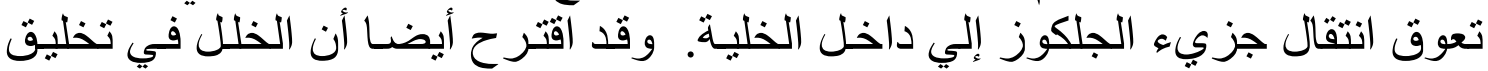

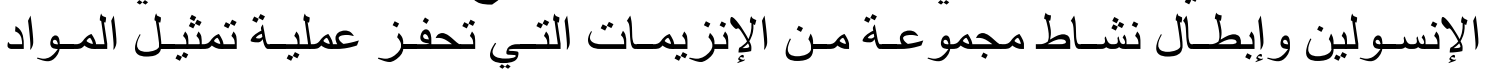

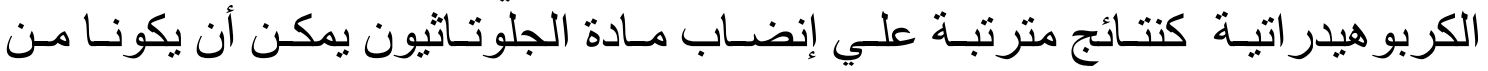

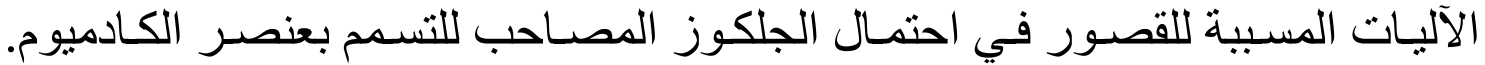

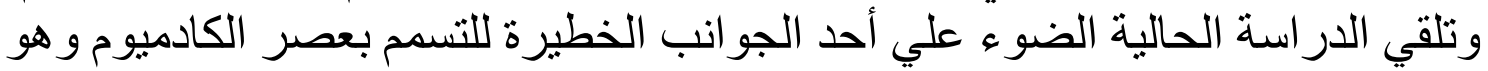

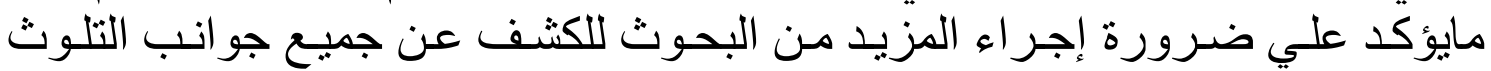

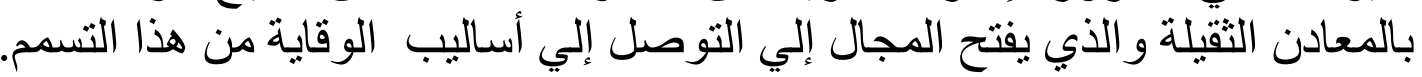

